\title{
THE EFFECTS OF TRADITIONAL CARE AND BIOPSYCHOSOCIAL DETERMINANTS ON THE RISK OF POSTPARTUM DEPRESSION: EVIDENCE FROM YOGYAKARTA
}

\author{
Selvia Febrianti'1), Didik Gunawan Tamtomo'2), Uki Retno Bbudihastuti3) \\ 1)Masters Program in Public Health, Universitas Sebelas Maret \\ 2)Faculty of Medicine, Universitas Sebelas Maret \\ 3)Department of Obstetrics and Gynecology, Dr. Moewardi Hospital, Surakarta
}

\begin{abstract}
Background: Previous studies expected that postpartum depression may occur from multiple hormonal-biological, psychological, familial, social, and cultural factors. The purpose of this study was to examine the effects of traditional care and biopsychosocial determinants on the risk of postpartum depression.

Subjects and Method: A cross sectional study was carried out at 25 birth delivery services in Sleman, Yogyakarta, from August to September 2019. A sample of 200 postpartum mothers was selected by multistage random sampling. The dependent variable was postpartum depression. The independent variables were sectio cesarean complication during labor, age, traditional birth delivery, education, family income, parity, unwanted pregnancy, and marriage satisfaction. The data were collected by questionnaire and analyzed by a multiple logistic regression.

Results: The risk of postpartum depression increased with sectio cesarean $(b=2.54 ; 95 \% \mathrm{CI}=$ 1.40 to $3.67 ; \mathrm{p}<0.001)$, complication during labor $(\mathrm{b}=3.13 ; 95 \% \mathrm{CI}=2.03$ to $4.22 ; \mathrm{p}<0.001)$, and age $\geq 35$ years old $(b=0.67 ; 95 \% \mathrm{CI}=-0.26$ to $1.62 ; \mathrm{p}=0.160)$. The risk of postpartum depression decreased with traditional birth delivery $(b=-0.99 ; 95 \% \mathrm{CI}=-1.93$ to $-0.05 ; \mathrm{p}=0.037)$, education $\geq$ Senior high school $(b=-1.75 ; 95 \% \mathrm{CI}=-3.13$ to $-0.38 ; \mathrm{p}=0.012)$, family income $\geq \mathrm{Rp} 1,701,000$ $(\mathrm{b}=-3.14 ; 95 \% \mathrm{CI}=-4.38$ to $-1.90 ; \mathrm{p}<0.001)$, multiparous $(\mathrm{b}=-1.14 ; 95 \% \mathrm{CI}=-2.14$ to $-0.14 ; \mathrm{p}=$ o.024), wanted pregnancy $(\mathrm{b}=-2.39 ; 95 \% \mathrm{CI}=-3.78$ to $-0.99 ; \mathrm{p}=0.001)$, and marriage satisfaction $(b=-1.18 ; 95 \% \mathrm{CI}=-2.15$ to $-0.20 ; \mathrm{p}=0.018)$.

Conclusion: The risk of postpartum depression increases with section cesarean, complication during labor, and age $\geq 35$ years old. The risk of postpartum depression decreases with traditional birth delivery, education $\geq$ Senior high school, family income $\geq R p$ 1,701,000, multiparous, wanted pregnancy, and marriage satisfaction.
\end{abstract}

Keywords: postpartum depression, biopsychosocial, traditional birth delivery care

\section{Correspondence:}

Selvia Febrianti. Masters Program in Public Health, Universitas Sebelas Maret. Jl. Ir. Sutami 36A, Surakarta, Central Java, Indonesia. Email: selvia.febri11@gmail.com. Mobile: $+628115939211$

The $7^{\text {th }}$ International Conference on Public Health

Solo, Indonesia, November 18-19, $2020 \mid 266$ https://doi.org/10.26911/the7thicph.03.86 